\title{
Evaluation of Strength in the "Toronto" Osseous-Prosthesis System
}

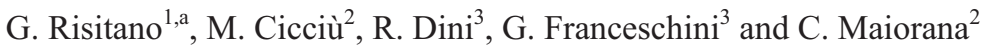 \\ ${ }^{1}$ Guglielmo Marconi University, Faculty of Applied Sciences, 00153 Rome, Italy \\ ${ }^{2}$ Department of Oral Surgery, I.C.P. Dental School University of Milan, Milano, Italy \\ ${ }^{3}$ Department Faculty of Engineering of Perugia, Department of Industrial Engineering, Perugia, Italy
}

\begin{abstract}
Several surgical techniques like are today available in order to recovery large bone defects of the jaw. Aim of the surgeon is to obtain a good tridimensional volume to place dental implant and to recovery the patient's aesthetics and function. Several prosthetic solution were considered for prosthetic rehabilitation. However after a bone graft surgery Toronto screwed prosthesis on dental implants, following Branemark intuitions, was considered the better prosthetic rehabilitation solution. According to Wölff, the dental implants osteointegration is related to the strengths directed to mandibular bone. Our investigation's aim is to underline through FEM analysis the stress over the prosthetic elements and over bone surface in order to help the surgeon choice about the dental implant positioning, and at the same time reducing the bone trauma on the patients.
\end{abstract}

\section{Introduction}

Dental implant application can be considered a common therapeutic procedure today. Even if there are a lot of different dental implants brand, the literature shows an approximate same survival percentage of the main producer industry. On the other hand talking about success of dental implant procedure, the only Branemark system is associated to a scientific and predictable long term results [1]. The 15 years follow up confirmed the predictable using of this brand of material. Every year about 36.000 dental implants are placed and the toronto screwed prosthesis application is rated to $7 \%$ of overall patients.

The knowledge on the strength distribution of the mandibular bone and over the dental implants should be very important for guarantee stability and osteointegration of the biomaterials. Several FEM studies tried to evaluate the real biomechanics indication for dental implant placement. Positioning, angulations and implant brand and surface are important parameters related to this kind of investigation. This topic is very debated in the literature and all the studies underlined how high is the overall investigation for the presence of several conditioning factors $[7-12,16]$.

\section{Aim of the work}

\footnotetext{
a e-mail : g.risitano@unimarconi.it
} 
Recently, the first investigation on the evaluation of the strength on the Toronto OsseousProsthesis system, was performed by the close collaboration between the Milano University Oral surgery team and Engineer Biomaterial team of the Perugia University. That first evaluation pointed out important results, even if the data obtained were relative to the Toronto prosthetic structure. The evaluation of the bone model was simplified and the characteristics of the bone tissue were considered standard. The study results suggested to perform future research creating a bone model in which the elastic features of the tissue were underlined on details by using CT investigation.

The oral cavity biomechanical analysis of the strength distribution is fundamental to avoid the system overloading (components fracture and lost of osseointegration). Engineer investigation of dental materials could be useful for a further microscopic data evaluation of the biomaterials. The clinicians should use safe and predictable material and technique avoiding overloading, non-success of the treatment and pain of the patients.

Clinical trials showed how those complications can happen; the risk of the passant screws and prosthesis fracture is high [15]. Zarb et Al. documented 13 cases on 21 on a study published on 1990 and Noert et Al. underlined 6 cases on 99 in an investigation published in 1992. The real common problem is that when one screws goes to fracture, the other screws modify their own stability.

Literature data show how the uncontrolled and unwilling closure of the mouth is repeated almost 2.000 times daily. If you consider that a dental implant should be maintained in the site for 10 years the act of closure will repeat on the implant surface for 7.300 .000 times undergoing resistance problems.

Aim of this work is improving the first investigation offering a mandibular bone model divided in 14 distinctive areas with marrow and cortical bone. An analyses of each prosthetic structures is also well performed. The final goal is to find the correct stress distribution of the mandibular strength in order to give to the surgeon further information in the dental implant positioning.

\section{Model and analysis description}

SolidWorks ${ }^{\circledR}$ software was used to create a CAD mandible - toronto dental implants model. This kind of engineer software is able to perform FEM analysis and CAD model creation at the same time. The internal softwares CosmosWork ${ }^{\circledR}$, Ansys ${ }^{\circledR}$ and Workbench ${ }^{\circledR}$ was then applied for making a quality improving of the models. This application was really useful cause the model and the FEM was performed inside the same software.

The creation of the models was performed step by step and the system was created developing the mandible model first, then the dental implant and after the prosthesis.

\subsection{Mandibular bone model}

TC brand new is today available in several italian hospitals in order to perform a threedimensional x-ray investigation on 64 levels. The three-dimensional reconstruction related to this new $\mathrm{x}$-ray machine is really fast and conventional axial images are not more utilized. This new technology offers the representation of complex anatomical area like human skull (figure 1a).

Working on this model by the SolidWorks software, just the edentulous mandible for dental implant placement and Toronto prosthesis application was investigated (figure 1b). Following literature references [14] about the mandibular bone characteristic, the cortical bone was recreated like deep 1,5 $\mathrm{mm}$ and the mandibular canal was considered $2 \mathrm{~mm}$. The cortical bone surrounding the canal was evaluated $4 \mathrm{~mm}$. Mandibular canal was not recreated to leave more easily the FEM investigation. Marrowbone and its elastic features were then recreated inside the cortical bone. According to other authors [18] the bone was then evaluated by biomechanics principles related to the different mandibular area and those parameters were also considered in the creation of the model obtaining seven values for the cortical bone and seven values for the marrow bone (figure 2). Table 1 shows these values. Cortical bone density was $1.800 \mathrm{~kg} / \mathrm{m}^{3}$, whilemarrow bone was $1.200 \mathrm{~kg} / \mathrm{m}^{3}$. Condyle area was considered not useful for the model and then deleted. Anisotropy bone 
characteristic is today a topic very debated in the literature, so for this reason the bone FEM was for a linear material with isotropic characteristics, even if with different biomechanics areas values (table 1).

(a)

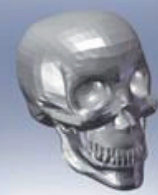

(b)

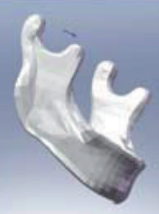

(c)

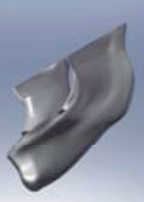

(d)

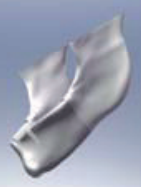

Fig. 1. (a) model of the skull, (b) model of the mandible, (c) model of cortical bone of the mandible, (d) model of marrow bone of the mandible.

Table 1. Mechanical properties of the seven areas of bone.

\begin{tabular}{|c|c|c|c|c|}
\hline $\begin{array}{c}\mathbf{N}^{\circ} \\
\text { area }\end{array}$ & $\mathbf{E}$ Cortical Bone [N/m2] & $\begin{array}{c}\mathbf{E} \text { Marrow Bone } \\
{[\mathbf{N} / \mathbf{m} 2]}\end{array}$ & $\begin{array}{c}\boldsymbol{v} \text { Marrow } \\
\text { Bone }\end{array}$ & $\begin{array}{c}\boldsymbol{v} \text { Marrow } \\
\text { Bone }\end{array}$ \\
\hline area 1 & $1,68 \mathrm{E}+10$ & $7,27 \mathrm{E}+08$ & 0,345 & 0,345 \\
\hline area 2 & $1,68 \mathrm{E}+10$ & $7,27 \mathrm{E}+08$ & 0,345 & 0,345 \\
\hline area 3 & $1,93 \mathrm{E}+10$ & $8,35 \mathrm{E}+08$ & 0,236 & 0,236 \\
\hline area 4 & $1,93 \mathrm{E}+10$ & $8,35 \mathrm{E}+08$ & 0,236 & 0,236 \\
\hline area 5 & $2,40 \mathrm{E}+10$ & $1,04 \mathrm{E}+09$ & 0,236 & 0,236 \\
\hline area 6 & $2,40 \mathrm{E}+10$ & $1,04 \mathrm{E}+09$ & 0,236 & 0,236 \\
\hline area 7 & $2,40 \mathrm{E}+10$ & $8,83 \mathrm{E}+08$ & 0,236 & 0,236 \\
\hline
\end{tabular}

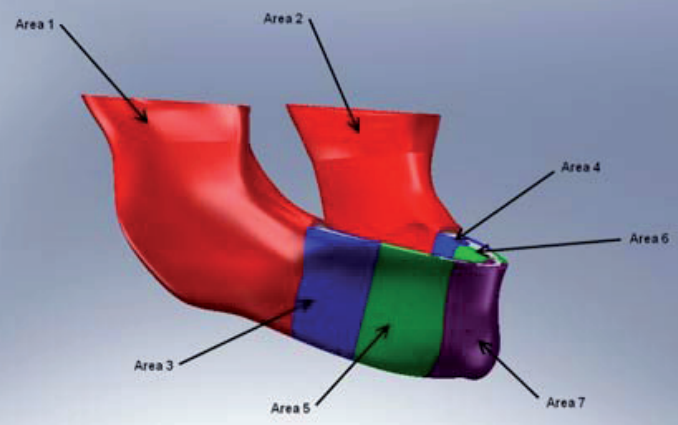

Fig. 2. The seven different areas of the model bone.

\subsection{Screw and dental implants models}

Solidworks software was then used for creating the dental implant, starting for some draws project giving by a leader producer company. Dental implants material is Titanium grade 4, known for its biocompatibility. The dental implants considered for this study are in trade by four years. The implant characteristic shows three different components; the fixture, placed into the bone; the 
abutment, for applying the toronto prosthesis structure, and the passant screw connecting abutment and fixture. Firstly FEM investigation was performed just in the fixture. Static trials were made with $800 \mathrm{~N}$ traction and compression strength. $45^{\circ} 566 \mathrm{~N}$ flexion strength was then applied to the abutment connected to the screw. The load considered were like the chewing loads according to references [15]. Data show how the passant connection screw is the more solicited part.

\subsection{Mandibular Toronto bridge prosthesis model}

Several sections simulated the Toronto Prosthesis structure. There are a lot of different Toronto Prosthesis model like circular $5 \times 5$ or L 6 x 4 . The model recreated followed a rectangular model $2 \times$ 2,4 $\mathrm{mm}$ according to Hobo and Stewart [15].

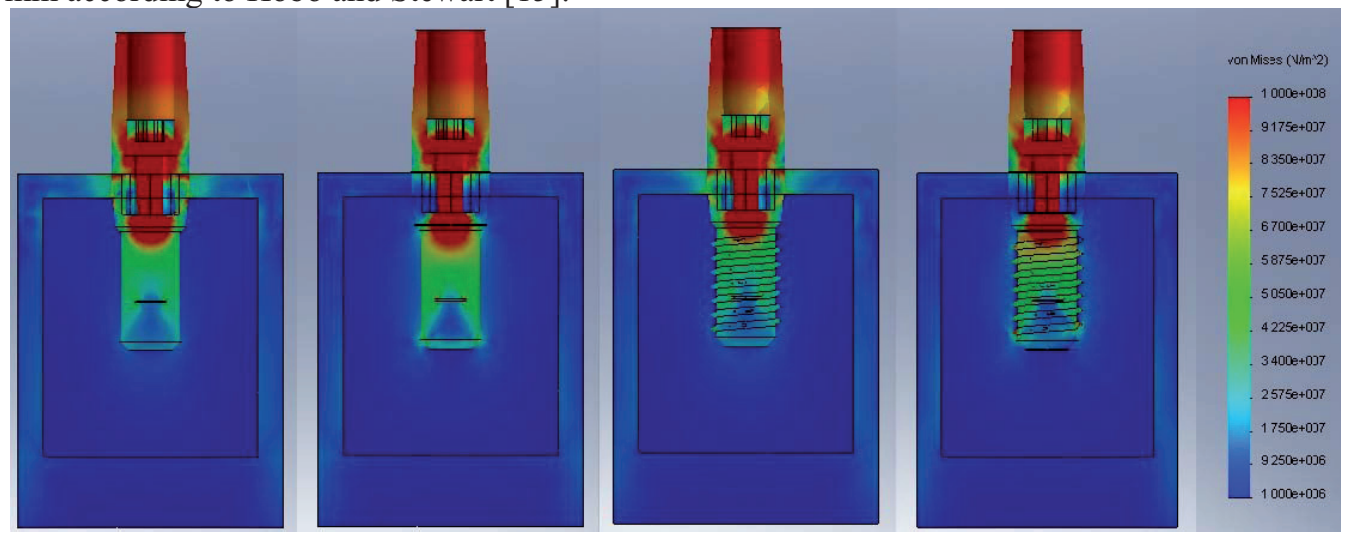

Fig. 3. Evaluation of the thread.

\section{4 "System" description}

The final mandibular model was completed by dental implant and prosthesis structure. Geometric analysis of each component was then needed to connect the different models. Parallelism, concentricity and coincidence were parameters related to Solidworks software. The fixture thread was related to the producer company and was not easy to represent by FEM all those characteristic. For this reason, the threads were deleted and a cube model created the entire components (Ansys $\left.{ }^{\circledR}\right)$. The cube was made by Titanium grade 4 and over it four different thread version were then created following a $3,8 \mathrm{~mm}$ diameter and a $8,5 \mathrm{~mm}$ length (figure 3 ):

1. Thread on fixture and passant screw;

2. Thread on passant screw;

3. Thread on the fixture;

4. No thread.

The considered threads have particular characteristics: $0,1 \times 0,2 \mathrm{~mm}$ and step like $0,3 \mathrm{~mm}$ for the passant screw; $0,1 \times 0.2$ with $025 \mathrm{~mm}$ step and 5 degrees angulation for the low area of the fixture; $0,05 \times 0,1 \mathrm{~mm}$ with $0,12 \mathrm{step}$ for the upper area of the fixture.

Cube was then soliciting with a $800 \mathrm{~N}$ one the abutment with fixed bond. All the tension obtained for the titanium cube analyses were similar. Considering a bone cube (figure 7) we obtained the same conclusion data even if we have to consider that the maximal strength in the fixture without thread was higher of the other cases with the threads (1). The results show how the thread absence causes the increasing of the structure rigidity and for this reason the weaker element has to support the highest load. From the other hand, the tensions are higher in the model with the threads and this is related to the micro connections of the thread steps $(1,4)$. Other two models show intermediate results. In the group with the passant screw without thread, the tensions on the passant screws are higher in the fixture thread model then without. While if consider the model through the fixture 
threads the ratio is opposite. This is because the contact between bone and fixture is higher then the contact between fixture and passant screw. Summarizing, using a safe model the average strength are just more then $13 \%$ of the total.

\subsection{Study objective}

In order to verify the quality of the FEM analysis model we considered a generic surgical trials like sample for our investigation. The surgeon suggested four different implant positions for Toronto supporting prosthesis.
1. 4 dental implants (a)
2. 6 dental implants (b)
3. 5 dental implants (c)
4. 8 dental implants (d)

It is important to underline how all those models are personal and so not universal. However, by surgeon experience, we have to consider the mental nerve position and dental implant placed in the between by 3 to $4,3 \mathrm{~mm}$ diameter and by 8 to $13 \mathrm{~mm}$ length. The diameter for the dental implant placed in the posterior area was consider by 3 to $5,5 \mathrm{~mm}$ diameter and by 8,5 to $13 \mathrm{~mm}$ on length.

From an engineer point of view the less safe model could be the one with four dental implants. The diameter chosen for the model fixture was $3,25 \mathrm{~mm}$ and the length was $8,00 \mathrm{~mm}$. The titanium toronto prosthesis structure was made on titanium grade six by a rectangular section $2 \times 2,4 \mathrm{~mm}$. The bone area was related according to the references and following the figure 2 and then each screw was named for the investigation (figure 4). About the model a1, a2, a3, length was $8 \mathrm{~mm}$ while 11 and 12 was $22,5 \mathrm{~mm}$. This value is different from the literature but as suggested by Rangert $(20 \mathrm{~mm})$ the model was created to evaluate hard geometry. Cantilever length 11 and 12 was made in order to try to consider the patient's complete dentition.

A symmetric load was then given to the model. Occlusion was considered and vertical stress of $50 \mathrm{~N}$ was applied to molar and premolar and $200 \mathrm{~N}$ on incisors and canine according to Carlsonn [15] considering a hard material bite. Figure 5 showed the loads distribution. A 3D FEM was then performed along the three principal axes with 10 nodes. The material was evaluated plastic and iperelastic with high deflexion.
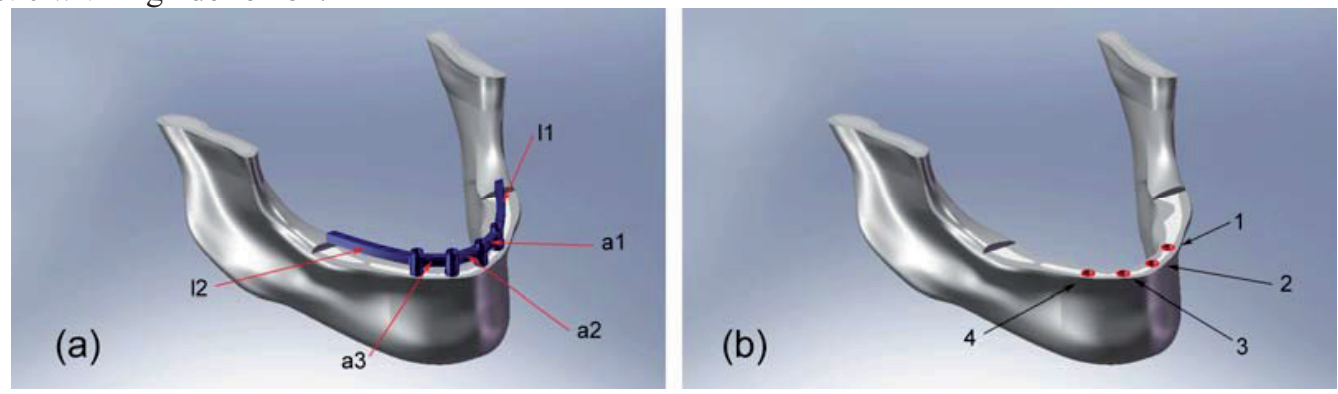

Fig. 4. The designations for the various parts of the frame (a) and screws (b).

\section{Results}

The date recorded for the system were:

1. Strength $(\sigma)$ and deformation $(\varepsilon)$, maxima, minima and average on the cortical bone, on the marrow bone and in the 7 different areas.

2. Strength $(\sigma)$ and deformation $(\varepsilon)$, maxima, minima and average on the 4 implant and in all the components (fixture, abutment and passant screw)

3. Strength $(\sigma)$ and deformation $(\varepsilon)$, maxima, minima and average on the Toronto prosthesis structure in 5 different areas. 
The results clearly demonstrated that the loads application have generated tensions safely stress on the implants on the passant screws, on the abutments and on the toronto structure. The fatigue resistance was clearly demonstrated.

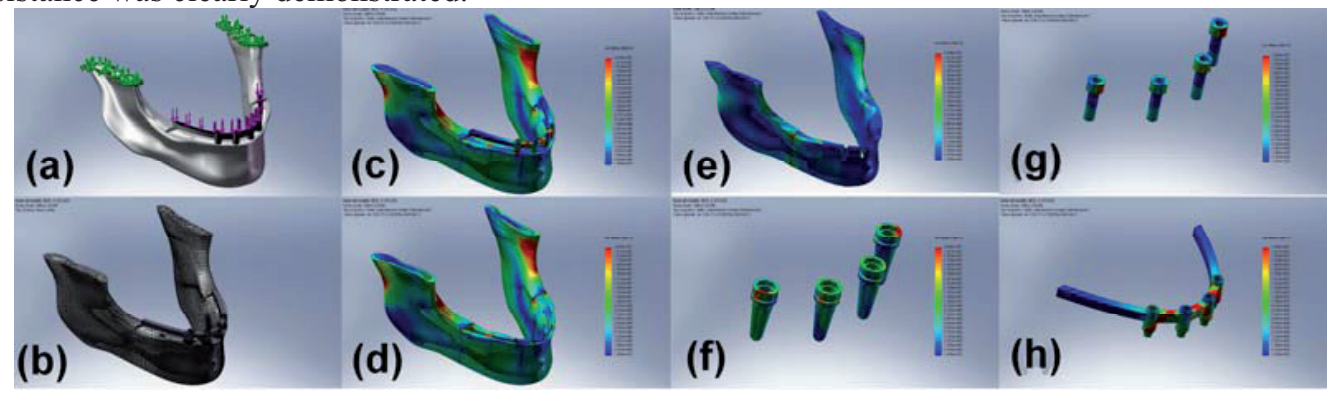

Fig. 5. (a) loads and constraints, (b) mesh, (c) Von Mises stress for the complete system, (d) Von Mises stress for cortical bone, (e) Von Mises stress on the marrow bone; (f) Von Mises stress for the fixture, (g) Von Mises stress for the screw connection, (h) of Von Mises stress for the loom.

\subsection{Bone analysis}

FEM evaluation of the bone showed that cortical bone is more rigid and better support when solicited all the strengths. The difference on percentage between the highest values is different on 30 $\%$ between the two bones. The difference on percentage between the values on average is almost 46 $\%$. Those results are comparable with the one showed by Silvestrini et Al.. The data from the clinical trials underlined how if there is a cortical bone contact with the dental implant, the marrow bone is not involved in the tensions distribution. The FEM showed how the bone pattern is different if analyzed in the different mandibular areas. Human mandibular bone is not homogenous and in some area the tensions analyzed can pass the value responsible for bone resorption. If we considered the highest tolerable bone value is like $2,8 \mathrm{MPa}$ [15] and that a transmission and stress diffusion can reach 5,6 $\mathrm{MPa}$ (double), we can consider our system safe because degenerative bone events happen at $8,4 \mathrm{MPa}$ (triple) even if the highest singular values of the system are close to 20 times upper the limit. Table 2 reports the values and the data related to the cortical and marrowbone. An example is in Figure 6, where the average stress on cortical and marrow bone are ploted.

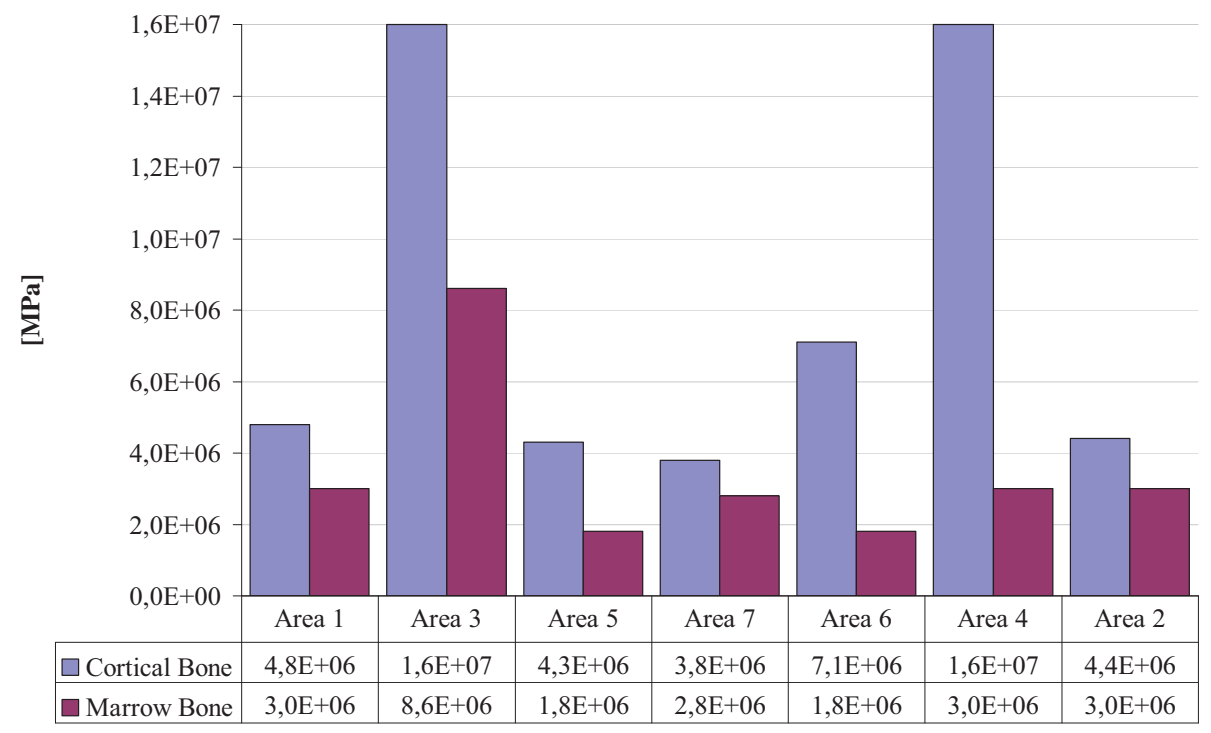

Fig. 6. Average stress on Bone. 
14th International Conference on Experimental Mechanics

Table 2. Maximum stress, minimum and average on Bone.

\begin{tabular}{|c|c|c|c|c|c|c|}
\hline \multirow[b]{2}{*}{$\mathbf{N}^{\circ}$ area } & \multicolumn{2}{|c|}{$\sigma_{M A X}-$ Von Mises $[M P a]$} & \multicolumn{2}{|c|}{$\sigma_{M I N}-$ Von Mises $[\mathrm{MPa}]$} & \multicolumn{2}{|c|}{$\sigma_{A V G}-$ Von Mises [MPa] } \\
\hline & $\begin{array}{c}\text { Cortical } \\
\text { Bone }\end{array}$ & $\begin{array}{c}\text { Marrow } \\
\text { Bone }\end{array}$ & $\begin{array}{c}\text { Cortical } \\
\text { Bone }\end{array}$ & $\begin{array}{c}\text { Marrow } \\
\text { Bone }\end{array}$ & $\begin{array}{c}\text { Cortical } \\
\text { Bone }\end{array}$ & $\begin{array}{c}\text { Marrow } \\
\text { Bone }\end{array}$ \\
\hline area 1 & $1,9 \mathrm{E}+08$ & $1,9 \mathrm{E}+08$ & $1,5 \mathrm{E}+05$ & $1,8 \mathrm{E}+04$ & $4,8 \mathrm{E}+06$ & $3,0 \mathrm{E}+06$ \\
\hline area 2 & $3,2 \mathrm{E}+07$ & $1,9 \mathrm{E}+08$ & $8,4 \mathrm{E}+04$ & $1,8 \mathrm{E}+04$ & $4,4 \mathrm{E}+06$ & $3,0 \mathrm{E}+06$ \\
\hline area 3 & $5,0 \mathrm{E}+08$ & $3,5 \mathrm{E}+08$ & $2,5 \mathrm{E}+05$ & $1,5 \mathrm{E}+05$ & $1,6 \mathrm{E}+07$ & $8,6 \mathrm{E}+06$ \\
\hline area 4 & $5,0 \mathrm{E}+08$ & $2,6 \mathrm{E}+07$ & $2,5 \mathrm{E}+05$ & $1,5 \mathrm{E}+05$ & $1,6 \mathrm{E}+07$ & $3,0 \mathrm{E}+06$ \\
\hline area 5 & $4,1 \mathrm{E}+07$ & $3,4 \mathrm{E}+07$ & $1,5 \mathrm{E}+05$ & $4,2 \mathrm{E}+03$ & $4,3 \mathrm{E}+06$ & $1,8 \mathrm{E}+06$ \\
\hline area 6 & $7,1 \mathrm{E}+07$ & $3,4 \mathrm{E}+07$ & $3,4 \mathrm{E}+05$ & $4,2 \mathrm{E}+03$ & $7,1 \mathrm{E}+06$ & $1,8 \mathrm{E}+06$ \\
\hline area 7 & $4,0 \mathrm{E}+07$ & $4,0 \mathrm{E}+07$ & $1,5 \mathrm{E}+05$ & $6,0 \mathrm{E}+04$ & $3,8 \mathrm{E}+06$ & $2,8 \mathrm{E}+06$ \\
\hline
\end{tabular}

\subsection{Prosthetic System}

FEM analysis was extended to the all components of the system. That was for evaluating the fracture limit of each component. Table 3 and figures 7 clearly showed the data related to the prosthetic elements of the system.

Table 3. Maximum stress, minimum and average of the components of the four screws.

\begin{tabular}{|c|c|c|c|}
\hline \multirow{2}{*}{$\mathbf{N}^{\circ}$ Screw } & \multicolumn{3}{|c|}{$\sigma_{\text {MAX }}$ - Von Mises [MPa] } \\
\cline { 2 - 4 } & Fixture & Screw Connection & Abutment \\
\hline $\mathbf{1}$ & $3,8 \mathrm{E}+07$ & $3,5 \mathrm{E}+07$ & $5,8 \mathrm{E}+07$ \\
\hline $\mathbf{2}$ & $4,0 \mathrm{E}+07$ & $2,1 \mathrm{E}+07$ & $4,0 \mathrm{E}+07$ \\
\hline $\mathbf{3}$ & $2,6 \mathrm{E}+07$ & $1,9 \mathrm{E}+07$ & $3,7 \mathrm{E}+07$ \\
\hline $\mathbf{4}$ & $3,7 \mathrm{E}+07$ & $2,8 \mathrm{E}+07$ & $5,1 \mathrm{E}+07$ \\
\hline \multirow{3}{*}{$\mathbf{N}^{\circ}$ Screw } & \multicolumn{3}{|c|}{$\sigma_{\text {MIN }}$ - Von Mises [MPa] } \\
\cline { 2 - 4 } & Fixture & Screw Connection & Abutment \\
\hline $\mathbf{1}$ & $2,6 \mathrm{E}+05$ & $3,4 \mathrm{E}+04$ & $1,2 \mathrm{E}+06$ \\
\hline $\mathbf{2}$ & $5,0 \mathrm{E}+05$ & $3,7 \mathrm{E}+05$ & $4,3 \mathrm{E}+05$ \\
\hline $\mathbf{3}$ & $7,3 \mathrm{E}+05$ & $1,8 \mathrm{E}+05$ & $4,7 \mathrm{E}+05$ \\
\hline $\mathbf{4}$ & $1,7 \mathrm{E}+05$ & $5,2 \mathrm{E}+04$ & $5,0 \mathrm{E}+05$ \\
\hline \multirow{3}{*}{$\mathbf{N}^{\circ}$ Screw } & \multicolumn{3}{|c|}{$\sigma_{\text {AVG }}-$ Von Mises [MPa] } \\
\cline { 2 - 4 } & Fixture & Screw Connection & Abutment \\
\hline $\mathbf{1}$ & $6,6 \mathrm{E}+06$ & $5,0 \mathrm{E}+06$ & $1,1 \mathrm{E}+07$ \\
\hline $\mathbf{2}$ & $6,0 \mathrm{E}+06$ & $5,0 \mathrm{E}+06$ & $9,8 \mathrm{E}+06$ \\
\hline $\mathbf{3}$ & $6,0 \mathrm{E}+06$ & $4,9 \mathrm{E}+06$ & $9,3 \mathrm{E}+06$ \\
\hline $\mathbf{4}$ & $5,4 \mathrm{E}+06$ & $4,9 \mathrm{E}+06$ & $9,1 \mathrm{E}+06$ \\
\hline
\end{tabular}




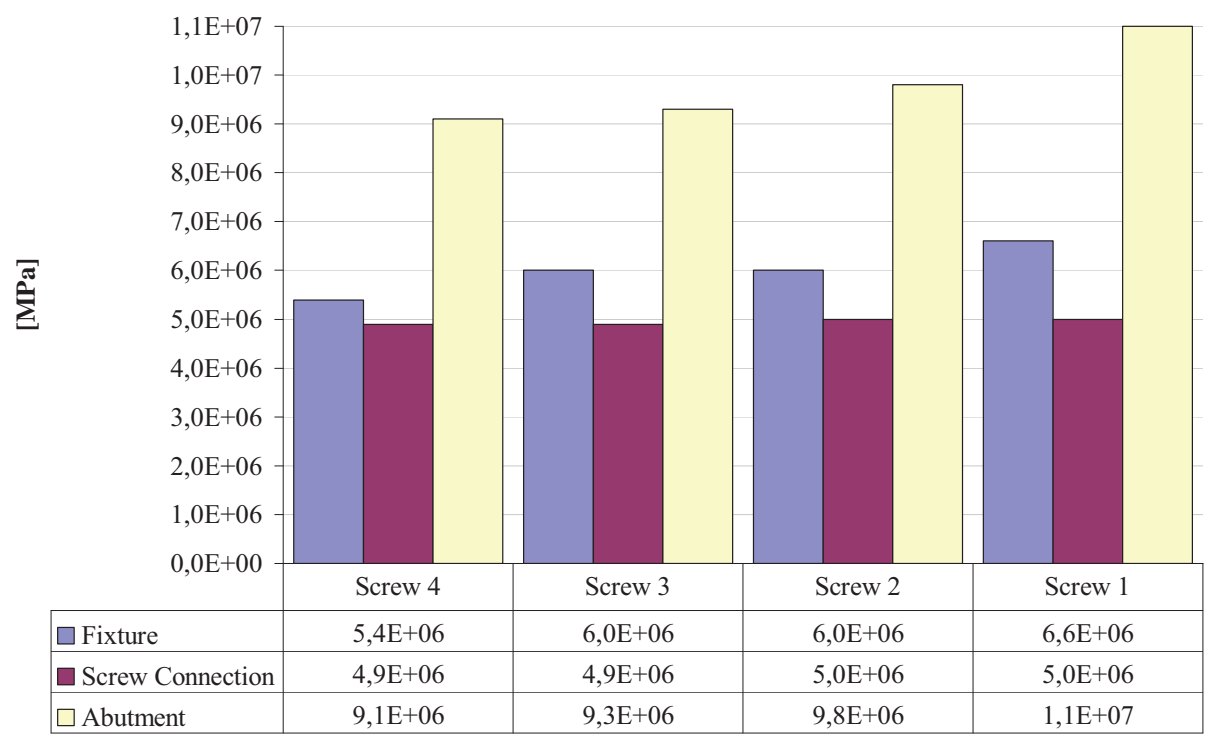

Fig. 7. Average stress on Prosthetic System.

\subsection{Structure analyses}

All the tensions and deformations of the connection portions (a1, a2, a3) and of the two cantilevers $(11,12)$ were recorded. Table 4 showed the high, average and minimum stress values; he a2 portion is the less solicited.

Table 4. Maximum stress, minimum and average on Loom.

\begin{tabular}{|c|c|c|c|}
\hline $\mathbf{N}^{\circ}$ loom & $\sigma_{\text {MAX }}$ - Von Mises [MPa] & $\sigma_{\text {MIN }}-$ Von Mises $[M P a]$ & $\sigma_{A V G}-$ Von Mises [MPa] \\
\hline $\mathbf{a 1}$ & $9,2 \mathrm{E}+07$ & $1,6 \mathrm{E}+06$ & $1,8 \mathrm{E}+07$ \\
\hline $\mathbf{a} 2$ & $5,0 \mathrm{E}+07$ & $1,8 \mathrm{E}+06$ & $1,6 \mathrm{E}+07$ \\
\hline $\mathbf{a 3}$ & $7,5 \mathrm{E}+07$ & $2,2 \mathrm{E}+06$ & $1,6 \mathrm{E}+07$ \\
\hline $\mathbf{l} 1$ & $3,0 \mathrm{E}+07$ & $1,2 \mathrm{E}+03$ & $2,8 \mathrm{E}+06$ \\
\hline $\mathbf{l} 2$ & $2,5 \mathrm{E}+07$ & $1,3 \mathrm{E}+03$ & $2,5 \mathrm{E}+06$ \\
\hline
\end{tabular}

\section{Conclusions}

This study is the result between the close collaboration between the Biomechanics Engineer team of Perugia University and the Oral Surgery Department of Milan University. Aim of the work was the creation of a model in order to "help" the surgeon in the choice of the dental implant placements following the biomechanics rules and the stress distribution over the mandible during the chew. CT data was utilized creating a CAD model. The entire component were divided and scanned step by step by FEM investigation even if the complexity of the model was related to the absence of references and to the new oral surgical topic. The final data and the well-represented distribution of the loads could be predictable and useful by the surgeon. Moreover, the several bone areas analyzed give the clinicians the opportunity to choice the better way of dental implants placement to obtain the fixture osseointegration and a well load distribution for better long term results. 


\section{References}

1. S.E.Eckert, A.Parein, H.L.Myshin, J.L.Padilla, Validation of dental implant systems through a review of literature supplied by system manufacturers, J Prosthet Dent, 77 (3):271-9 9069082 (P,S,E,B), Mar 1997

2. S. E. Clift, J. Fisher, C. J. Watson, Finite element stress and strain analysis of the bone surrounding a dental implant: effect of variations in bone modulus, Proc Instn Mech Engrs, Vol. 206, 1992

3. D. Siegele, U. Soltesz, H. Scheicher, Dental implants inserts - A possibility to improve the stress distribution in the jaw, Fraunhofer - Institute fur Werkstoffmechanik, Freiburg, F.R.G., 1985

4. D. Siegele, U. Soltész, Numerical investigations of the influence of implant shape on stress distribution in the jaw bone, The international Journal of Oral \& Maxillofacial Implants, Vol. 4, 1989, pp. 333-340

5. S. E. Clift, J. Fisher, C. J. Watson, Stress and strain distribution in the bone surrounding a new design of dental implant: a comparison with a threaded Branemark type implant, Proc Instn Mech Engrs, Vol. 207, 1993

6. S. E. Clift, J. Fisher, B. N. Edwards, Comparative analysis of bone stresses and strains in the Intoss dental implant with and wiyhout a flexible internal post, Proc Instn Mech Engrs, Vol. 207, 1995

7. Y. Matsushita, M. Kitoh, K. Mizuta, H. Ikeda, T. Suetsugu, Two-dimensional FEM analysis of hidroxyapatite implants: diameter effects on stress distribution, Journal of oral implantology, Vol. XVI, 1990

8. H.J.A. Meijer, F.J.M. Starmans, F. Bosman, W.H.A. Steen, A comparison of three finite element models of an edentulus mandible provided with implants, Journal of oral rehabilitation, Vol. 20, 1993, pp. 147-157

9. L. A. Weinberg, The biomechanics of force distribution in implant-supported prostheses, The International Journal of Oral \& Maxillofacial Implants, Vol.8, pp. 19-31, 1993

10. C. Ko Ching, D. H. Kohn, S. J. Hollister, Micromechanics of Implant / Tissue Interfaces, Journal of Implantology, Vol. XVIII, 1992

11. E. Armentani, F. Caputo jr., R. Citarella, R. Esposito, M. Infante, G. Lavorgna, Sulla valutazione numerica delle condizioni elastostatiche di un impianto dentario endosseo, Atti del 29mo convegno nazionale AIAS, Lucca, settembre, 2000

12. Haldun Iplikcioglu, Kivanc Akca, Comparative evaluation of the effect of diameter, length and number of implants supporting three-unit fixed partial prostheses on stress distribution in the bone, Journal of Dentistry, Vol. 30, 2002, pp. 41-46

13. R. Pietrabissa, R. Contro, V. Quaglini, M. Soncini, L. Gionso, M. Simion, Experimental and computational approach for the evaluation of the biomechanical effects of dental bridge misfit, Journal of Biomechanics, Vol.33, 2000, pp.1489-1495 (in Italian)

14. Bono B., Girello A., Gerarci D., Indagine numerica e sperimentale sullo stato di sollecitazione indotte nel perimpianto dentario, AIAS XXXII Convegno Nazionale, Salerno, 2003 (in Italian)

15. E. Gherlone, La protesi su impianti osteointegrati, Masson, Milano, 2004 (in Italian)

16. Citarella R., Esposito R., Infante M., Analisi tensionali di un impianto dentario endosseo con il boundary element method (BEM), AIAS XXXII Convegno Nazionale, Salerno, 2003 (in Italian)

17. M.Cicciù, G. Franceschini, C. Maiorana, G. Risitano; Studio parametrico delle tensioni nel sistema osso-protesi tipo "Toronto"; VII Giornata di Studio, AIAS, Biomateriali e Biomeccanica, Catania, 13 luglio 2007 (in Italian)

18. E. Armentani, C. Calì, F. Caputo, R. Citarella, M. Infante, G. Lavorgna, Modello agli elementi di contorno per l'analisi tensionale dell'articolazione temporo-mandibolare, AIAS XXXI Convegno Nazionale, Parma, 2002 (in Italian) 